\title{
EFFECT OF DIETARY MORINGA (Moringa oleifera) SEEDS INCLUSION ON PERFORMANCE OF BROILER CHICKENS
}

\author{
Baraa F. I. Elbushra, Magda Elmahdi ${ }^{2}$ and H. E. Hassan ${ }^{3}$ \\ ${ }^{2}$ Department of Animal Production, Faculty of Agriculture, University of Sinnar, Abunaama, Sudan \\ ${ }^{3}$ Faculty of Animal Production, University of Gezira,Sudan.
}

SUMMARY

$\mathrm{T}$ he experiment was conducted at Abu Naama area- about 400 kilometers south Khartoum-to determine the effect of dietary Moringa oleifera seeds supplementation on the performance of broiler chickens and carcass characteristics. A total of 160 one day old Ross 308 broilers were distributed into 4 groups (treatments) with 4 replicates containing 10 chicks each. Four broiler rations were formulated with graded levels of Moringa oleifera seeds $(0,0.5,1$ and $2 \% / \mathrm{kg})$. All diets were kept isocaloric with a metabolizable energy $3200 \mathrm{kcal} / \mathrm{kg}$ diet. The experiments have lasted for 44 days of age. All chicks were fed on a starter diet for 2 days (adaptation period). The results of feed intake showed that there were significant different $(\mathrm{P} \leq 0.05)$ between the treatments through all weeks. The birds fed the control diet had a greatest feed consumption throughout the experimental period except at week four of age, at which the birds fed diets containing $1 \%$ Moringa consumed the largest amount of feed $(\mathrm{p} \leq 0.05)$. The effect of varying levels of Moringa oleifera seeds on weekly weight gain showed that, there were significant different $(\mathrm{P} \leq 0.05)$ between the treatments through all weeks except the first one. The control group ( $0 \%$ moringa) achieved a significantly highest weight gain values through all weeks except the fourth one. There were significant different $(\mathrm{P} \leq 0.05)$ between the treatments through the third, fourth, fifth and sixth weeks of age. The control $(0 \%$ moringa) gave a significantly worst feed conversion value through the third and fourth weeks. Group fed $1 \%$ moringa recorded highest values in the fifth week. Moreover, group fed $2 \%$ moringa recorded highest values in the sixth one. There were highly significant different $(\mathrm{P} \leq 0.01)$ between the treatments (mean values) for rib back, wings, carcass shrinkage and hind back percent. Moreover, there were significant different $(\mathrm{P} \leq 0.05)$ between the treatments (mean values) for warm carcass, cold carcass, left side, right side and all values of the parts and cuts except dressing empty body and muscles percent. The highest ratio of mortality observed at group with $2 \%$ Moringa oleifera while the level $0.5 \%$ recorded no mortality rate. On the other hand, the mortality rate of unsupplemented group was $5 \%$.

\section{INTRODUCTION}

The rapid growth of human and livestock population is creating increased needs for food and feed in the less developed countries demands that alternative feed resources must be identified and evaluated (odunsii, 2003). Researchers have great interest in finding natural growth promoters to enhance poultry production and to reduce feed cost. Plant products have been used for centuries by humans as food and to treat ailments. Natural medicinal products originating from herbs and spices have also been used as feed additives for farm animals (Guo, 2003). In many tropical and subtropical countries, various parts of Moringa oleifera (leaves, fruits, immature pods, and flowers) are incorporated into the traditional food of humans (Siddhuraju and Becker, 2003 and Anhwange et. al, 2004). Leaves of the moringa tree are the preferred part for use in animal diets as leaf meal. Research was conducted to study the effect of this leaf meal on the growth performance of layer chicks (Melesse et. al, 2011), productive performance of laying hens (Kakengi et. al, 2007, Olugbemi et. al, 2010 and Abou-Elezz, 2011) on broilers' performance (Juniar et. al, 2008 and Olugbemi et. al, 2010), and on the growth, carcass, and blood indices of weaner rabbits (Nuhu, 2010). The effect of Moringa oleifera seeds on broilers' performance was also examined by researchers (Abbas, 2012). Moringa oleifera is a plant that possess multiple advantages, because different parts of the tree (leaves, fruits, immature pods and flowers) are edibles and entered in traditional diets in many tropics and sub-tropics countries (Siddhuraju and Becker, 2003; Anhwange et al., 2004). Jahn (1986) mentioned that rural women in Sudan use Moringa oleifera seeds instead of alum to remove turbidity from Nile water. Eilert et al. (1981) reported that Moringa oleifera seeds have antimicrobial effects. Madsen et al. (1987) found that use of Moringa oleifera seeds reduced bacterial count of turbid Nile water in Sudan by 1-4 log units (90-99.9\%) within the 


\section{Elbushra et al.}

first 1-2 hours of treatment. In addition, Walter et al. (2011) assured that Moringa oleifera and Moringa stenopetala methanol and n-hexane seed extracts produced inhibition effect on Salmonella typhii, Vibrio cholerae and Escherichia coli, which normally cause water borne diseases. Regarding chemical composition, Compaoré et al. (2011) reported that Moringa oleifera seeds are good source of fats, proteins and minerals. This research was performed to examine the effect of Moringa oleifera seeds powder in the broilers diet on their performance and carcass characteristics.

\section{MATERIALS AND METHODS}

\section{Study area}

This study was conducted at Abu Naama area about 400 kilometers South Khartoum at the Faculty of Agriculture, Sinnar University. The area at latitud $12^{\circ} .44^{\prime} \mathrm{N}$ and longitude $34^{\circ} .08^{\prime} \mathrm{E}$, altitude, 445 meter above sea level. The rainfall was approximately $600-800 \mathrm{ml}$ annually, and the maximum and minimum temperature ranged between 35.6 to 43.7 and 23.2 to 26.0 minimum.

\section{Moringa oliefera collection and preparation}

Moringa oleifera seeds were collected from Abu Naama area. The seeds were sorted, cleaned and ground to powder using grinding machine. The grounded seeds were compounded into feed for the feeding experiment. The ground seeds were included in experimental diet in following proportion $0 \%, 0.5 \%, 1 \%$ and $2 \%$.

\section{Housing management and duration of experiment}

The experiment was carried out in an open system-oriented house, which was located east - west direction to a void solar radiation. The open sides of the house measured $8 \times 12 \mathrm{~m}$ and $2.5 \mathrm{~m}$ high. The roof was constructed with corrugated irons sheets built from cement bricks and wires. Before the commencement of the experiments, the houses were cleaned and disinfected using formalin solution. Dry wood shavings were used as a litter material with a depth of approximately $6 \mathrm{~cm}$. A total of 16 pens measuring $159 \mathrm{~m}$ area were divided using wire rots as partitions each pen was supplied with a feeder and a drinker about 40 and 20 $\mathrm{cm}$ in diameter retrospectively. Throughout the experimental period light was provided for $24 \mathrm{hrs} .12 \mathrm{hrs}$ on day light and the rest on artificial lighting, using 40 watt bulbs. The electrical bulbs were initially kept at about $15 \mathrm{~cm}$ above the ground to provide heat and then raised gradually to a height of $1.75 \mathrm{~m}$ towards the end of the experimental period chicks, immediately after hatching were vaccinated against Marek's disease and Newcastle disease. At day 12 post hatching they were also vaccinated against Gomboro. The experiment was conducted for a period of 6 weeks, with adaptation period, starter and finisher periods 1,3 and 2 week each respectively. Temperature and humidity were recorded at the mid of the day using a normal thermometer and hygrometer.

\section{Experimental chicks}

A lot of 160 day-old, unsexed commercial broiler chicks (Ross 308) were used and assigned into 16 pens (in groups of 10 chicks in a pen).

\section{Experimental rations}

Each pen was provided with feeder and drinker. Each experimental diet was fed to 4 replicates, in a completely randomized design. Broiler chicks were kept on a deep litter floor system. Four experimental isocaloric and isonitrogenous diets were formulated to meet or exceed the NRC (1994) requirements of broiler chicks (Table 3). One group was kept as control while the other three experimental diets contain $0.5,1$, and $2 \%$ Moringa Oleifera. Feed (Table1) and water was provided adlibitum.

\section{Morenga seeds chemical analysis}

Moringa sample were analyzed at Agricultural Research Cooperation-Wed Medani. Proximate chemical analysis and anti-nutritional factors and protein digestibility of Moringa seeds removal hulls content $51.8 \%$ crude protein, $25.7 \%$ oil, $11 \%$ crude fiber and $4.7 \%$ ash. M.E content was $13.39 \mathrm{k} \mathrm{cal} / \mathrm{kg}$ on dry matter basis. (Table2). 


\section{Statistical Analysis}

The data generated from the experiment was subjected to analysis of variance -Complete Randomized Design (CRD) according to SPSS (1990). Duncan's Multiple range tests (DMRT) was used to assess significance of Difference between means as described by Little and Hills (1978).

Table (1): The Composition of Experimental diets and The Chemical Composition of Moringa Oliefera seeds percentage.

\begin{tabular}{lcccccccc}
\hline Ingredient & \multicolumn{2}{c}{$0 \%(\mathrm{M} . \mathrm{S})$} & \multicolumn{2}{c}{$0.5 \%(\mathrm{MS})$} & \multicolumn{2}{c}{$1 \%(\mathrm{MS})$} & \multicolumn{2}{c}{$2 \%(\mathrm{MS})$} \\
\cline { 2 - 8 } & Starter & Finisher & Starter & Finisher & Starter & Finisher & Starter & Finisher \\
\hline Sorghum (feterita) & 58.00 & 61.00 & 57.50 & 61.00 & 57.50 & 61.00 & 57.00 & 61.50 \\
Ground nut Cake & 16.40 & 08.10 & 16.50 & 08.10 & 16.60 & 08.30 & 17.10 & 08.60 \\
Sesame Cake & 14.00 & 11.00 & 14.00 & 11.00 & 14.00 & 11.00 & 14.00 & 11.50 \\
Wheat bran & 02.50 & 09.50 & 02.40 & 09.00 & 01.80 & 08.30 & 00.80 & 06.00 \\
Super Concentrate & 05.00 & 05.00 & 05.00 & 05.00 & 05.00 & 05.00 & 05.00 & 05.00 \\
Lysine & 00.10 & 00.10 & 00.10 & 00.10 & 00.10 & 00.10 & 00.10 & 00.10 \\
Oyster shell & 00.30 & 00.70 & 00.30 & 00.70 & 00.30 & 00.70 & 00.30 & 00.70 \\
Dicalcium phosphate & 01.20 & 00.60 & 01.20 & 00.60 & 01.20 & 00.60 & 01.20 & 00.61 \\
Oil & 02.00 & 03.00 & 02.00 & 03.00 & 02.00 & 03.00 & 02.00 & 03.00 \\
Na Cl & 00.25 & 00.25 & 00.25 & 00.25 & 00.25 & 00.25 & 00.25 & 00.25 \\
Vitamin(Premix) & 00.25 & 00.25 & 00.25 & 00.25 & 00.25 & 00.25 & 00.25 & 00.25 \\
Moringa Seeds & 00.00 & 00.00 & 00.50 & 00.50 & 01.00 & 01.00 & 02.00 & 02.00 \\
\hline
\end{tabular}

M.S=Moringa oleifera seed

Table (2):The Chemical Composition of Moringa Oliefera seeds percentage.

\begin{tabular}{lc}
\hline Moisture\% & 2.85 \\
\hline Oil & 25.750 \\
Sodium & 09.700 \\
Phosphorus & 00.535 \\
Potassium & 00.200 \\
Protein & 51.800 \\
Total carbohydrate & 15.5 \\
N3O & 00.045 \\
M.E (mg/100g) & 3.39 \\
\hline Department of Animal Nutrition -Agricultural Research Cooperation-Medan
\end{tabular}

Table (3): Requirements of experimental chicks according to (NRC,1994)

\begin{tabular}{lcc}
\hline Nutrient & Starter $\%$ & Finisher\% \\
\hline Grude protein & 23 & 18 \\
Metabolizable energy & 3100 & 3200 \\
Calcium & 0.9 & 1.0 \\
Phosphorus & 2.3 & 1.8 \\
Lysine & 1.0 & 1.2 \\
Methionine & 0.72 & 0.83 \\
\hline
\end{tabular}




\section{Elbushra et al.}

\section{RESULTS}

The effect of varying levels of Moringa oleifera on weekly feed intake is presented in Table (4). There were significant different $(\mathrm{P} \geq 0.05)$ between the treatments through all weeks. The birds fed the control diet had the greatest feed consumption throughout the experimental period except at week four of age, at which the birds fed diets containing $1 \%$ moringa consumed the largest amount of feed $(\mathrm{p} \leq 0.05)$. The control $(0 \%$ moringa) gave significantly the highest feed intake values through all weeks except at the fourth one. $1 \%$ moringa recorded highest values in the fourth week. The birds fed the control diet had greatest feed consumption throughout the experimental period except at week four age, at which the birds fed diets containing $1 \%$ moringa consumed the largest amount of feed $(\mathrm{p} \leq 0.05)$.

\section{Effect of Moringa oleifera levels on weight gain of broiler chicken}

The effect of varying levels of Moringa oleifera seeds on weekly weight gain is presented in Table (5). There were significant different $(\mathrm{P} \geq 0.05)$ between the treatments through all weeks except the first one. The control $(0 \%$ moringa) gave a significantly highest weight gain values through all weeks except the fourth one. Similar results were obtained by their counterparts $\mathrm{C}$ and $\mathrm{D}$, which also, had the largest weight gain at weeks $(2,3$ and 4$)$ and $(3,4$ and 5), respectively). $1 \%$ and $2 \%$ moringa recorded highest values in the fourth week. Similar results were obtained by their counter parts C and D, which also, had the largest weight gain at weeks $(2,3$ and 4$)$ and (3,4 and 5), respectively.

\section{Effect of Moringa oleifera levels on feed conversion ratio of broiler chickens}

The effect of varying levels of Moringa oleifera on weekly feed conversion ratio is presented in table (6). There were significant different $(\mathrm{P} \geq 0.05)$ between the treatments through the third, fourth, fifth and sixth weeks of age. The control $(0.0 \%$ moringa) gave a significantly worst feed conversion value through the fourth weeks while $1 \%$ moringa recorded worst values in the fifth week. Moreover, $2 \%$ moringa recorded worst values in the six one.

\section{Effect of Moringa oleifera levels on carcass characteristics of broiler chickens}

The effect of varying levels of Moringa oleifera on carcass characteristics is presented in table (4) There were highly significant different $(\mathrm{P} \geq 0.01)$ between the treatments (mean values) for rib back, wings, carcass shrinkage and hind back percent. $1 \%$ level obtain the best carcass, breast and drumstick. Moreover, there were significant different $(\mathrm{P} \geq 0.05)$ between the treatments (mean values) for warm carcass, cold carcass, left side, right side and all values of the parts and cuts except dressing empty body and muscles percent.

\section{Effect of Moringa oleifera levels on mortality of broiler chickens}

The mortality ratios were presented in Table (5). The highest ratio of mortality observed at group $2 \%$ while the level $0.5 \%$ recorded no mortality rate. On the other hand, the mortality rate of un-control group was $5 \%$.

Table (4): Weekly average feed intake values of experimental chicks fed different levels of Moringa seeds for 42 days (gram/chick)

\begin{tabular}{ccccccc}
\hline \multirow{2}{*}{ Week } & \multicolumn{3}{c}{ Treatment } & \multirow{2}{*}{ SE } & \multirow{2}{*}{ Sig. } \\
\cline { 2 - 4 } & $\mathrm{A}(0 \% \mathrm{M} . \mathrm{S})$ & $\mathrm{B}(0.5 \% \mathrm{M} . \mathrm{s})$ & $\mathrm{C}(1 \% \mathrm{M} . \mathrm{s})$ & $\mathrm{D}(2 \% \mathrm{M} . \mathrm{s})$ & & \\
\hline $1^{\text {st }}$ week & $100.00^{\mathrm{a}}$ & $94.00^{\mathrm{b}}$ & $93.00^{\mathrm{b}}$ & $90.00^{\mathrm{b}}$ & 1.205 & $*$ \\
$2^{\text {nd }}$ week & $377.45^{\mathrm{a}}$ & $358.25^{\mathrm{c}}$ & $370.45^{\mathrm{b}}$ & $357.98^{\mathrm{c}}$ & 1.2125 & $*$ \\
$3^{\text {rd }}$ week & $617.73^{\mathrm{a}}$ & $588.33^{\mathrm{b}}$ & $592.50^{\mathrm{b}}$ & $569.43^{\mathrm{c}}$ & 1.96 & $*$ \\
$4^{\text {th }}$ week & $807.73^{\mathrm{b}}$ & $761.75^{\mathrm{c}}$ & $906.85^{\mathrm{a}}$ & $780.16^{\mathrm{c}}$ & 1.6575 & $*$ \\
$5^{\text {th }}$ week & $1001.63^{\mathrm{a}}$ & $949.75^{\mathrm{c}}$ & $987.75^{\mathrm{b}}$ & $930.13^{\mathrm{c}}$ & 1.5725 & $*$ \\
$6^{\text {th }}$ week & $1160.80^{\mathrm{a}}$ & $1066.13^{\mathrm{c}}$ & $1092.40^{\mathrm{b}}$ & $1036.50^{\mathrm{d}}$ & 1.52 & $*$ \\
\hline
\end{tabular}

Means in a row followed by the same letter are not significantly different ( $p \geq 0.05)$.

SE:Standard error of means

M.S: Moringa oliefera seeds

*: Significant at level 0.05 
Table (5): Weekly average weight gain values of experimental chicks fed different levels of Moringa seeds for 42days. (gram/chick)

\begin{tabular}{|c|c|c|c|c|c|c|}
\hline \multirow[t]{2}{*}{ Weeks } & \multicolumn{4}{|c|}{ Treatment } & \multirow[t]{2}{*}{ SE } & \multirow[t]{2}{*}{ Sig. } \\
\hline & A (0\% M.S) & B (0.5\%M.s) & C (1\%M.s) & D (2\%M.s) & & \\
\hline $1^{\text {st }}$ week & $87.75^{\mathrm{a}}$ & $87.62^{\mathrm{a}}$ & $87.37^{\mathrm{a}}$ & $87.87^{\mathrm{a}}$ & 3.65 & N.S \\
\hline $2^{\text {nd }}$ week & $270.35^{\mathrm{a}}$ & $260.62^{\mathrm{b}}$ & $265.22^{\mathrm{ab}}$ & $258.8^{\mathrm{c}}$ & 4.025 & $*$ \\
\hline $3^{\text {rd }}$ week & $419.82^{\mathrm{a}}$ & $380.5^{\mathrm{b}}$ & $413.35^{\mathrm{ab}}$ & $411.13^{\mathrm{ab}}$ & 3.2 & $*$ \\
\hline $4^{\text {th }}$ week & $470.30^{\mathrm{b}}$ & $458.75^{\mathrm{b}}$ & $510.23^{\mathrm{a}}$ & $502.87^{\mathrm{a}}$ & 2.955 & $*$ \\
\hline $5^{\text {th }}$ week & $500.70^{\mathrm{a}}$ & $445.38^{\mathrm{c}}$ & $463.48^{\mathrm{b}}$ & $488.85^{\mathrm{ab}}$ & 3.675 & $*$ \\
\hline $6^{\text {th }}$ week & $524.17^{\mathrm{a}}$ & $524.17^{\mathrm{a}}$ & $479.8^{\mathrm{b}}$ & $431.83^{\mathrm{b}}$ & 3.525 & $*$ \\
\hline
\end{tabular}

Means in a row followed by the same letter or no letter subscript are not significantly different $(P>0.05)$.

SE:Standard error of means

M.S :Moringa Oliefera seeds

*: Significant at level 0.05

N.S: Not Significant

Table (6): Weekly average feed conversion ratio values of experimental chicks fed different levels of Moringa seeds for 42days. (gram/chick).

\begin{tabular}{lcccccc}
\hline \multirow{2}{*}{ Week } & \multicolumn{3}{c}{ Treatment } & \multirow{2}{*}{ SE } & \multirow{2}{*}{ Sig. } \\
\cline { 2 - 5 } & A $(0 \% \mathrm{M} . \mathrm{S})$ & $\mathrm{B}(0.5 \% \mathrm{M} . \mathrm{s})$ & $\mathrm{C}(1 \% \mathrm{M} . \mathrm{s})$ & $\mathrm{D}(2 \% \mathrm{M} . \mathrm{s})$ & & \\
\hline $1^{\text {st }}$ week & $1.12 \pm 2.10^{\mathrm{a}}$ & $1.11 \pm 2.30^{\mathrm{a}}$ & $1.13 \pm 2.20^{\mathrm{a}}$ & $1.11 \pm 2.30^{\mathrm{a}}$ & 2.225 & N.S \\
$2^{\text {nd }}$ week & $1.36 \pm 2.40^{\mathrm{a}}$ & $1.37 \pm 2.33^{\mathrm{a}}$ & $1.39 \pm 2.37^{\mathrm{a}}$ & $1.38 \pm 2.45^{\mathrm{a}}$ & 2.3875 & N.S \\
$3^{\text {rd }}$ week & $1.45 \pm 4.44^{\mathrm{ab}}$ & $1.54 \pm 4.30^{\mathrm{a}}$ & $1.45 \pm 4.43^{\mathrm{ab}}$ & $1.39 \pm 6.01^{\mathrm{b}}$ & 4.795 & $*$ \\
$4^{\text {th }}$ week & $1.71 \pm 6.21^{\mathrm{a}}$ & $1.66 \pm 3.67^{\mathrm{a}}$ & $1.58 \pm 4.65^{\mathrm{b}}$ & $1.55 \pm 6.74^{\mathrm{b}}$ & 5.3175 & $*$ \\
$5^{\text {th }}$ week & $2.00 \pm 4.02^{\mathrm{ab}}$ & $1.86 \pm 3.64^{\mathrm{b}}$ & $2.12 \pm 4.66^{\mathrm{a}}$ & $1.90 \pm 3.77^{\mathrm{b}}$ & 4.0225 & $*$ \\
$6^{\text {th }}$ week & $2.21 \pm 3.11^{\mathrm{b}}$ & $2.22 \pm 4.00^{\mathrm{b}}$ & $2.33 \pm 3.54^{\mathrm{ab}}$ & $2.49 \pm 6.22^{\mathrm{a}}$ & 4.2175 & $*$ \\
\hline
\end{tabular}

Means in a row followed by the same letter or no letter subscript are not significantly different $(p>0.05)$.

$S E:$ Standard error of means

M.S :Moringa oliefera seeds

*: Significant at level 0.05

N.S: Not Significant 


\section{Elbushra et al.}

Table (7). Effect of Moringa oleifera levels on Carcass characteristics values of broiler chickens (6 weeks).

\begin{tabular}{|c|c|c|c|c|c|}
\hline Item & $\mathrm{A}(0 \%)$ & $\mathrm{B}(0.5 \%)$ & $\mathrm{C}(1 \%)$ & $\mathrm{D}(2 \%)$ & Sig \\
\hline Warm carcass & $1666.00 \pm 75.53^{d}$ & $1806.00 \pm 68.41^{b}$ & $1918.26 \pm 36.76^{\mathrm{a}}$ & $1708.50 \pm 55.01^{\mathrm{c}}$ & $*$ \\
\hline Cold carcass & $1600.00 \pm 72.22^{\mathrm{c}}$ & $1697.50 \pm 69.56^{b}$ & $1797.50 \pm 34.73^{\mathrm{a}}$ & $1608.25 \pm 54.17^{\mathrm{c}}$ & $*$ \\
\hline Left side & $844.25 \pm 37.81^{b c}$ & $901.65 \pm 34.72^{b}$ & $953.75 \pm 19.72^{\mathrm{a}}$ & $850.00 \pm 28.93^{b c}$ & $*$ \\
\hline Right side & $830.00 \pm 38.91^{b}$ & $913.32 \pm 38.31 \mathrm{a}$ & $963.25 \pm 17.11^{\mathrm{a}}$ & $858.25 \pm 26.56^{b}$ & $*$ \\
\hline Rib back & $55.00 \pm 3.53^{\mathrm{c}}$ & $63.32 \pm 4.24^{b}$ & $76.75 \pm 3.11^{\mathrm{a}}$ & $73.75 \pm 2.39^{a b}$ & $* *$ \\
\hline Hind part & $91.75 \pm 26.69^{c}$ & $141.75 \pm 6.56^{\mathrm{ab}}$ & $120.00 \pm 2.04^{b}$ & $151.75 \pm 3.11^{\mathrm{b}}$ & $*$ \\
\hline Round & $131.75 \pm 716^{b}$ & $153.25 \pm 4.25^{\mathrm{a}}$ & $150.00 \pm 2.08^{a}$ & $138.25 \pm 3.11^{\mathrm{b}}$ & $*$ \\
\hline Drumstick & $116.75 \pm 3.11^{\mathrm{b}}$ & $110.0 \pm 5.40^{\mathrm{c}}$ & $120.00 \pm 4.08^{\mathrm{ab}}$ & $121.75 \pm 3.11^{\mathrm{a}}$ & $*$ \\
\hline Breast & $321.75 \pm 49.84^{b}$ & $296.25 \pm 12.14^{\mathrm{c}}$ & $336.50 \pm 8.25^{\mathrm{a}}$ & $276.75 \pm 20.75^{b c}$ & $*$ \\
\hline Wings & $83.25 \pm 2.35^{b}$ & $93.25 \pm 5.13^{b}$ & $106.75 \pm 5.13^{\mathrm{a}}$ & $91.75 \pm 1.18^{\mathrm{c}}$ & $* *$ \\
\hline Neck & $118.25 \pm 3.11^{\mathrm{a}}$ & $131.75 \pm 1.18^{b}$ & $92.50 \pm 27.4^{\mathrm{c}}$ & $118.75 \pm 3.14^{\mathrm{a}}$ & $*$ \\
\hline Dressing on slaughter & $70.25 \pm 0.75^{d}$ & $72.40 \pm 2.66^{c}$ & $73.45 \pm 1.20^{b}$ & $74.28 \pm 0.93^{\mathrm{a}}$ & $*$ \\
\hline Dressing empty body & $79.19 \pm 0.35^{\mathrm{a}}$ & $78.32 \mathrm{a} \pm 3.02^{\mathrm{a}}$ & $79.29 \pm 1.12^{\mathrm{a}}$ & $80.14 \pm 2.38^{\mathrm{a}}$ & N.S \\
\hline Carcass shrinkage & $4.19 \pm 0.14^{\mathrm{c}}$ & $6.04 \pm 0.33^{a}$ & $6.30 \pm 0.12^{\mathrm{a}}$ & $5.87 \pm 0.44^{b}$ & $* *$ \\
\hline Mussels weight & $1197.50 \pm 77.92^{c}$ & $1316.75 \pm 27.28^{\mathrm{a}}$ & $1385.00 \pm 43.49^{\mathrm{a}}$ & $1253.25 \pm 19.21^{\mathrm{b}}$ & $*$ \\
\hline Bone & $362.50 \pm 27.19^{c}$ & $375.00 \pm 15.5^{\mathrm{bc}}$ & $387.50 \pm 9.46^{b}$ & $403.25 \pm 10.27^{\mathrm{a}}$ & $*$ \\
\hline Muscles percent & $74.78 \pm 3.66^{\mathrm{a}}$ & $73.74 \pm 0.9^{\mathrm{a}}$ & $72.81 \pm 1.14^{\mathrm{a}}$ & $73.29 \pm 0.57^{\mathrm{a}}$ & NS \\
\hline Bone percent & $22.69 \pm 1.15^{\mathrm{d}}$ & $24.28 \pm 0.23^{b}$ & $25.07 \pm 1.25^{\mathrm{a}}$ & $23.61 \pm 0.16^{\mathrm{c}}$ & $*$ \\
\hline Rib back percent & $6.60 \pm 0.12^{\mathrm{c}}$ & $7.08 \pm 0.76^{b}$ & $8.1 \pm 0.25^{\mathrm{a}}$ & $8.7 \pm 0.31^{\mathrm{a}}$ & $*$ \\
\hline Hind back percent & $14.77 \pm 0.74^{\mathrm{c}}$ & $15.71 \pm 0.55^{b}$ & $12.67 \pm 0.60^{\mathrm{d}}$ & $17.8 \pm 0.78^{a}$ & $* *$ \\
\hline Drumstick percent & $14.14 \pm 0.33^{\mathrm{a}}$ & $12.20 \pm 0.42^{b}$ & $12.67 \pm 0.36^{b}$ & $14.33 \pm 0.80^{\mathrm{a}}$ & $*$ \\
\hline Round & $15.61 \pm 0.32^{\mathrm{c}}$ & $17.05 \pm 0.50^{\mathrm{a}}$ & $15.84 \pm 0.37^{\mathrm{c}}$ & $16.20 \pm 0.21^{\mathrm{b}}$ & $*$ \\
\hline Breast percent & $32.04 \pm 0.52^{b}$ & $32.74 \pm 0.39^{b}$ & $35.59 \pm 1.22^{\mathrm{a}}$ & $35.52 \pm 2.91^{\mathrm{a}}$ & $*$ \\
\hline Wing percent & $10.06 \pm 0.63^{b}$ & $10.32 \pm 0.26^{b}$ & $11.25 \pm 0.36^{\mathrm{a}}$ & $10.76 \pm 0.22^{\mathrm{ab}}$ & * \\
\hline Neck percent & $14.23 \pm 0.45^{\mathrm{a}}$ & $14.62 \pm 0.53^{\mathrm{a}}$ & $12.83 \pm 0.65^{\mathrm{c}}$ & $13.97 \pm 0.73^{b}$ & $*$ \\
\hline Liver wet $(\%)$ & $1.70 \pm 0.45^{b}$ & $1.90 \pm 0.45^{\mathrm{a}}$ & $1.71 \pm 0.45^{b}$ & $1.70 \pm 0.45^{b}$ & $*$ \\
\hline Intestine weightt (\%) & $4.10 \pm 0.41^{\mathrm{a}}$ & $4.00 \pm 0.41^{\mathrm{a}}$ & $3.60 \pm 0.45^{b}$ & $4.00 \pm 0.41^{\mathrm{a}}$ & $*$ \\
\hline Intestine length (cm) & $188 \pm 0.23^{\mathrm{a}}$ & $175 \pm 0.45^{c}$ & $185 \mathrm{a} \pm 0.45^{\mathrm{b}}$ & $180 \pm 0.45^{b}$ & $*$ \\
\hline Gizzard weight (\%) & $1.76 \pm 0.22^{c}$ & $2.07 \pm 0.25^{\mathrm{b}}$ & $2.19 \pm 0.22^{\mathrm{ab}}$ & $2.24 \pm 0.21^{\mathrm{a}}$ & $*$ \\
\hline Fat weightt (\%) & $1.76 \pm 0.41^{\mathrm{b}}$ & $1.95 \pm 0.45^{\mathrm{a}}$ & $1.92 \pm 0.41^{\mathrm{a}}$ & $1.30 \pm 0.45^{\mathrm{c}}$ & $*$ \\
\hline
\end{tabular}

Means in a row followed by the same letter or no letter subscript are not significantly differen $t(p>0.05)$.

M.S :Moringa Oliefera seeds

*and**: Significant at level 0.05 and 0.01 , respectively.

N.S: Not Significant

\section{DISCUSSTION}

Nutrition accounts for $60-70 \%$ of the total production cost in modern poultry production systems. Natural medicinal products originating from herbs and spices have been used as feed additives for farm animals (Guo, 2003). In most developing countries, the major sources of protein in commercial poultry production are Fish meal (FM) and oil seed cakes. However, these are usually scarce, expensive and used extensively by other livestock and humans. Moringa oleifera seed supplement have been included into the diets of poultry as means of reducing high cost conventional protein sources (Makkar and Becker, 1996). Moringa Oliefera seeds as other legumes. The protein concentration $(253.5$ to $264.3 \mathrm{~g} / \mathrm{kg}$ ) and crude fiber levels varied from $(51.5 \%$ to $58.1 \%)$. The result obtained by Henshaw, 2008 showed that there were difference in protein contents, where Moringa olifera seeds contained appreciable amount of crude protein (39.1\%), crude fiber 
(11\%), moisture (2.85\%), ash (4.7\%) and oil (39.1\%), respectively. In the present study the chemical composition of Moringa oleifera seeds results for crude protein (51.8\%) value was similar to those from Malaysia with 38\% (Abdulkrium et., al 2005) and pakestan (Anwar, et al, 2006) have found a value ranging from $29.6 \%$ to $31.3 \%$. Protein seeds of Moringa Oliefera in this study is greater than those reported for imported grain legumes and cereals which contain in general 18\% to $25 \%$ of dry matter (Singh and Singh,1992). The protein analysis by Nzikou et al.(2009) in Congobrazzvaile by the method of microkjeldahl revealed a value of $37.6 \%$. These seeds are a potentially good sources of proteins and oil which should be exploited to determine if they are commercially viable. The differences in high content and low content of protein can be attributed to geographical location, soil composition, cultivation, climate, ripening stage, differences in the locality of it is growth, the stage at maturity prior to harvesting and the extraction method used. 25.1\% C.P of leaves in an experiment where extract and un-extracted leaves of Moringa oliefera were used as a component of animal feed (Makkar and Becker ,1996). Anwar et al. (2006) have found after oil extraction by hexane method $38.7 \%$. The variation observed in the Moringa oliefera seeds with regards to oil content may have been due to either a different genetic makeup of the plants on more probably due to environmental effects and variation in oil content across countries might be attributed to the environmental and geological conditions in the regions Nzikou et al., (2009) have found a value of carbohydrates13.6 and Abdulkarim et al (2005) reported a range value of it was about 16.5 to $17.8 \%$. Nzikou et al.,(2009) found that crude fiber value of (3.2) while (Anwar et al., 2006) have found a range value of (6.6\% to 9\%). Although crude fiber does not contribute to nutrients or energy, it is source of dietary fiber. Minerals of Moringa oliefera seeds Ca++ $\left(83.75+\_0.01 \mathrm{mg} / 100 \mathrm{~g}\right) \mathrm{Mg}++(251++0.02 \mathrm{mg} / 100 \mathrm{~g})$., p (36.53+_0.02mg/100g)., Na++ (22.5+_0.01 mg/100g) (Nzikou et al.,2009) .These values are slight higher than these results of the current study. Although the atomic absorption spectrophotometer method has been used for minerals analysis. The greater content of total phenol $(237.77 \mathrm{mg} / 100 \mathrm{~g})$ was observed with the seeds of Moringa oliefera Comparing these results with the literature, values that differed from results were found by Compaoré et al (2011). The variation may be due to differences in varieties, climate, ripeness and extraction method. According to the results obtained seeds of Moringa oliefera were found the most active one with an anti-oxidante value, it has higher phenolic content with good correlation (Nzikou et al.,2009) also it content slight appreciable of tannin $(0.028 \mathrm{mg} / 100)$. There is no available literature information about the content of phenolic compounds and /or the anti-oxidant capacity. Based on the profile of Moringa oliefera seeds dietary treatments had no negative effect on broiler chicks feed consumption during the experimental period. The feed consumption values were negatively affected for the birds fed $2 \%$ level at moringa dietary inclusion. When age advanced the feed consumption values not affected negatively for the birds fed $1 \%$ Moringa seed .This slight improvement might due to improvement of tolerance of off-taste resulting from higher inclusion of moringa in the diet (Table 4). Similar feed intake was observed in all groups, since all diets were aporoximately iso-calaric and iso-nitrogenous. Consequently, the weight gain improved when the age advanced due to increase in moringa utilization for $\mathrm{C}$ and $\mathrm{D}$ treatments (Table 5). It also, might be attributed to birds capability to resist the moringa anti nutritional factors.Generally, in the present study there is no tendency for feed consumption and performances. These trend does not agree with various reports from other studies in (Moringa oliefera leaf), notably those by Guo et al (2003). Olugbemi et al (2010) who used Moringa stenopetala, which indicated that performance improvement was associated with leaf meal dietary inclusion rate not exceeding 5- 6\% (Cariaso1988). In other study showed reduction in birds' performance at higher leaf meal inclusion levels in the range of $7.5 \%-10$. Reduction in performance at higher dietary levels of Moringa oliefera leaf meal that attributed to anti-nutritional factors in the leaf meal, Makar and Becker (1996), mentioned that Moringa oliefera seeds contain appreciable amount of antinutritional factors compared with leaves of Moringa oliefera. Reduction in weight gain, feed efficiency and body weight as a result of addition of higher level of Moringa oliefera. ( $2 \%$ ) to broilers diet during starter period may be due to the presence of phytate which is considered as anti- nutritional factor. Makkar and Becker (1997) reported that extracted kernel and extracted seed meal of Moringa oleifera have higher levels of phytate. As mentioned by some researchers, phytate reduced bioavailability of minerals in non-ruminant animals (Reddy et al., 1982) and decline digestibility of starch and protein (Thompson, 1993). But this negative effect appeared to be overcome during whole periods Moringa oliefera include antibacterial materials as reported by Eilert et al (1981). Also Madsen et al (1987) mentioned that use of Moringa oleifera seeds reduced bacterial count of turbid Nile water in Sudan by 1-4 log units (90-99.9\%) within the first 1-2 hours of treatment. Furthermore, Walter et al (2011) noticed that Moringa oleifera and Moringa stenopetala methanol and n-hexane seed extracts produced inhibition effect on Salmonella typhii, Vibrio cholerae and Escherichia coli, which normally cause water borne diseases. Compaoré et al (2011) mentioned that Moringa oleifera seeds are considered as a good source of fat, protein, antioxidants and minerals $(\mathrm{Mg}$ and $\mathrm{Zn}$ ), so it can overcome malnutrition due to micronutrients deficiencies in children. Increase in 


\section{Elbushra et al.}

abdominal fat weight with increased supplementation level of Moringa oleifera to broiler chicks' diet. The lower feed intake of broiler chicks fed on diet contains Moringa oliefera seeds may be attributed to the bitter taste in the seeds of the Moringa oliefera, whereby made the consumption of feeds so less that usually which that taste refers to the saponins. The seeds bitter taste is generally attributed to alkaloids, saponins, cyanogenic glucosides and glucosinolates which are removed by treatment, suggesting that this taste would not limit the use of this material in animal diets. There is considerable genetic diversity between Moringa oliefera and Moringa stenopetala, for example, Odee (1998) reported that there are many different varieties whose kernels taste from sweet to very bitter. Seeds of some varieties are consumed by humans after roasting and taste like peanuts. Ramachandran et al., (1980). The effect of inclusion $2 \%$ decorticated Moringa oliefera Seeds instead of commercial concentrate in broiler chicks' diet on daily feed intake observed that the amount of the feed intake so less. Reduction in weight gain, and body weight gain as a result of addition of higher level of Moringa oliefera seeds to broilers diet during th experiment period may be due to the presence of phytate which is considered as anti-nutritional factor. Makkar and Becker (1997) reported that extracted kernel and extracted seed meal of Moringa oliefera have higher levels of phytate .AS mentioned by some researchers, phytate reduced bioavailability of minerals in non-ruminant animals Reddy et al.,(1982) and decline digestibility of starch and protein Thompson (1993).But this negative effect appeared to be overcome during finisher and whole periods due to the presence of benefit factors in Moringa oliefera seeds including antibacterial materials as reported by Eilert et al (1981). Compaore et al. (2011) mentioned that Moringa oliefera seeds are considered as a good source of fat, protein, antioxidants and minerals ( $\mathrm{Mg}$ and $\mathrm{Zn}$ ), so it can overcome malnutrition due to micronutrients deficiencies in children. Data of carcass characteristics indicated a significant difference $(\mathrm{P} \leq 0.05)$ in carcass weight and dressing percentage in chicks fed Moringa oliefera seeds compared that with Moringa oliefera leaf meal these results are disagree with result reported by Ibrahim (2005). Moringa oliefera seeds were better during the starter and finisher period and lowered gain were observed during the starter period, these observation may be related to the presence of some anti-nutritional factors of Moringa oliefera seeds Igwilo et al. (2010). All these factors faced the trial no mortality mentioned at the whole period of experiment and we exert most effort at that period of the experiment. The tree, according to Fahey et al .,(2001) has in recent decade been shown to be an outstanding indo-genous source of highly digestible protein, calcium, iron, vitamin $\mathrm{C}$ and carotenoids suitable for utilization in many of the so-called "developing" regions of the world where undernourishment is a major concern.

\section{CONCLUSION}

According to the results obtained from the research it was concluded that higher levels of Moringa oleifera seeds in the broiler chicks die adversely affected the performance. Therefore, it is suggested that Moringa oleifera should be included in broiler diet with low levels.

\section{REFERENCES}

Abbas TE, Ahmed ME. (2012).Use of Moringa oleifera seeds in broilers diet and its effects on the performance and carcasscharacteristics. Inter J Appl Poult ; 1: 1-4.

Abdulkarim,S.M ; Long.k; Lai,O.M ;Mohammed, S.K.S; Ghazali .H.M.(2005).Some physic-chemical properties of Moringa oliefera seed oil extract using solvent and aqueous enzymatic mrthod s. food chem.;93 (2) :253-263.

Abou-Elezz F.M.K, Sarmiento-Franco L, Santos-Ricalde R, Solorio-Sanchez F. (2011). Nutritional effects of dietary inclusion of Leucaena leucocephala and Moringa oleifera leaf meal on Rhode Island Red hens' performance. Cub J Agri Sci ; 45:163-169.

Anhwange B.A, VO Ajibola and S.J Oniye. (2004). Chemical studies of the seeds of Moringa oleifera (Lam.) and Detarium microcarpum (Guill and Sperr). J Biol Sci, 4: 711-715.

Anwar, F; Zafar ,S.N. and Rashid, U.( 2006).Characterization of Moringa oleifera seed oil from drought and irrigated regions of Punjab Grasasy Aceites ,57 (2):160-168. 
Cariaso. E.R. (1988). Feeding value of mallunggay (Moringa oliefera) leaf meal in broiler diet. College of agriculture, university of the Philippines, los banos thesis.

Compaoré W.R, P.A Nikièma, HIN Bassolé, A Savadogo, JMouecoucou, DJ Hounhouigan and SA Traoré. (2011). Chemical composition and antioxidative properties of seeds of Moringa oleifera and pulps of Parkia biglobosa and Adansonia digitata commonly used in food fortification in Burkina Faso. Curr Res $\mathbf{J}$ Biol Sci, 3 (1): 64-72.

Eilert .U, B .Wolters, and A Nahrstedt.(1981). The antibiotic principle of Moringa oleifera and Moringa stenopetala. Planta Med, 42: 55-61.

Fahey, J.W; Zakmann , A.T.and Talalay, P. (2001). The chemical diversit and distribution of glucosinolates and iso-thiocyanates among plants. phyto- chemistry .59:200-a,237.

Guo. F.C (2003). Mushroom and herb polysaccharides as alternative for antimicrobial growth promoters in poultry. Ph. D. Dissertation, Wageningen Institute of 4 Int J App Poult, 1(1): 1-4. Animal Sciences, Department of Animal Nutrition, Wageningen University, Netherlands.

Igwilo, I . O ; Ezeonu, F . C ; Udedi . S . C ; Okonkwo , C . J . and Ozumba . N . A (2010). Nutrient composition, protein quality and anti-nutritional factors in the seeds of Moring Oleifera grown in Awka, Anambra state,Nigeria Vol. 6. issue 4.

Jahn S.A.A.( 1986). Proper use of African natural coagulants for rural water supplies - Research in the Sudan and a guide to new projects. GTZ Manual No. 191. Little TM and FJ

Juniar I, Widodo E, Sjofjan O. (2008).Effect of Moringa oleifera leaf meal in feed on broiler production performance. Jurnal Ilmuilmu Peternakan Brawijaya; 18: 238-242.

Kakengi A.M.V, Kaijage J.T, Sarwatt S.V, Mutayoba SK, Shem MN, Fujihara T.(2007) .Effect of Moringa oleifera leaf meal as a substitute for sunflower seed meal on performance of laying hens in Tanzania. Livest Res Rur Dev; 19: article \#120. Available a http://www.lrrd.org/lrrd19/8/kake19120.htm.

Madsen M, J Schlundt, and EF El-Omer (1987). Effect of water coagulated by seeds of Moringa oleifera on bacterial concentrations. J Trop Med Hygiene, 90: 101-109.

Makker, H.P.S. and Becker, K (1996) . Nutritional value and ant-nutritional com- ponent of whole and ethanol extract Moringa oleifera .leaves .anim. feed,sci. tech : 63,211-228.

Makkar H.P.S and K Becker, (1997). Nutrients and antiquality factors in different morphological parts of Moringa oleifera tree. J Agric Sci, 128: 311-322.

National Research Council .(1994). Nutrient Requirements of Poultry. 9th edition. National Academic Press. Washington D.C.

Nuhu F. (2010). Effect of Moringa leaf meal (MOLM) on nutrient digestibility, growth, carcass and blood indices of weaner rabbits. MSc, Faculty of Agriculture and Natural Resources, Kwame Nkrumah University of Science and Technology, Kumasi, Ghana.

Nzikou, J.M; L. Matos, J.E; Moussounga , C.B; Ndangui, A; Kimbonguila, T.H. Silou, M.Linder and Desobry,S.(2009).Characterization of Moringa oleifera seed oil variety Congo Brazzaville . J . Food Technol., 7 (3): 59-65.

Odansi , A . A . (2003) : assessment of lablab (lablab purpureus ) leaf meal as meal as a feed Ingredients and yolk coloring agent in the diet journal of poultry science, 2 (1) 71 - 74 .

Odee, D .(1998) : forest biotechnology research in dry lands of Kenya : the development of moringa species . dry biodivers . 12 (3) : 7-8.

Olugbemi TS, Mutayoba SK, Lekule FP. (2010). Evaluation of Moringa oleifera leaf meal inclusion in cassava chip based diets fed to laying birds. Livest Res Rur Dev 22: article 118.

Ramachandran C , Peter KV ,Gopalakrishnan PK.Drumstik (moriga oliefera ) (1980): a multipurpose Indian vegetable Econ Bot. 34 (3): 276-83

Reddy NR, SK Sathe, and DK Salunkhe .( 1982). Phytates in legumes and cereals. Adv Food Res, 28: 1-92. SAS Institute, 1990. SAS/STAT User's Guide: Statistics. Release 8.2 SAS Institute Inc., Cary, NC. 


\section{Elbushra et al.}

Thompson LU, 1993. Potential health benefits and problems associated with antinutrients with foods. Food Res. Inter. 26: 131-149.

Siddhuraju P and K Becker.( 2003). Antioxidant properties of various solvent extracts of total phenolic constituents from three different agro-climatic origins of drumstick tree (Moringa oleifera L.). J Agri Food Chem, 15: 2144-2155.

Thompson L.U, (1993). Potential health benefits and problems associated with antinutrients with foods. Food Res. Inter. 26: 131-149.

Walter A, W Samuel, A Peter, and O Joseph.( 2011). Antibacterial activity of Moringa oleifera and Moringa stenopetala methanol and n-hexane seed extracts on bacteria implicated in water borne diseases. Afri J Microbiol Res, 5 (2): 153-157.

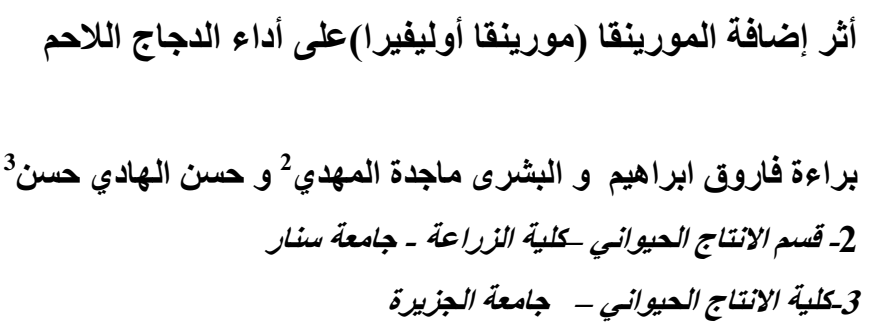

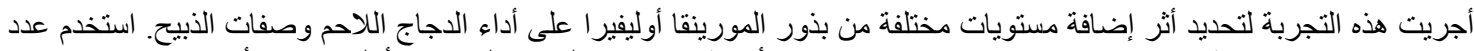

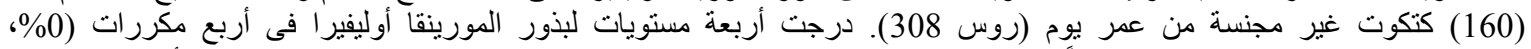

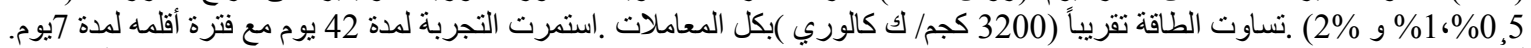

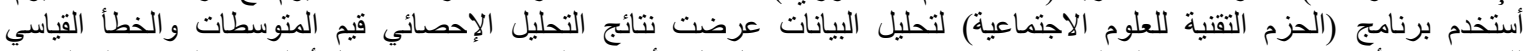

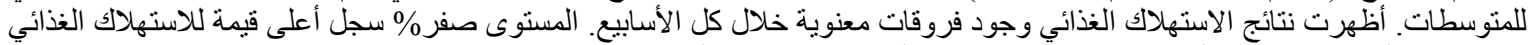

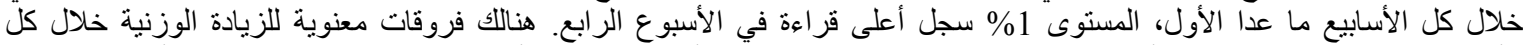

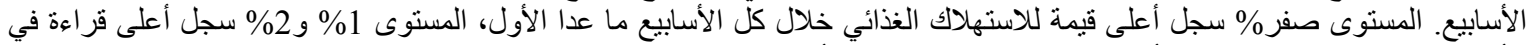

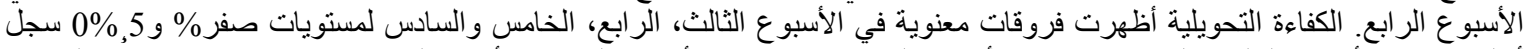

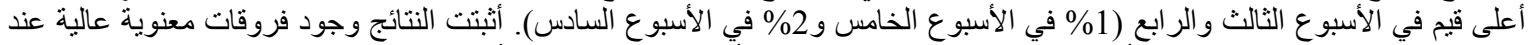

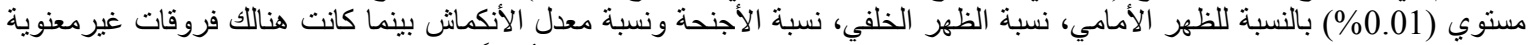

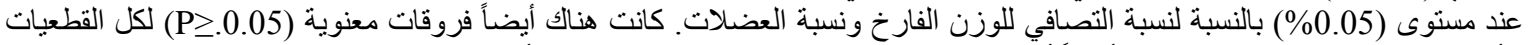

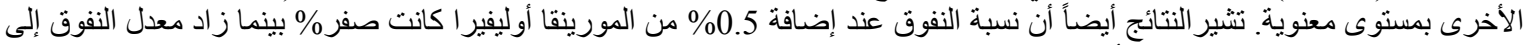

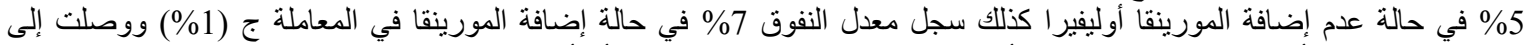

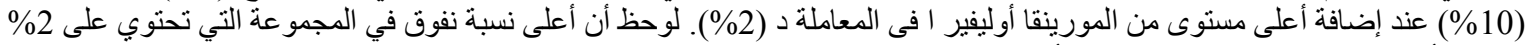

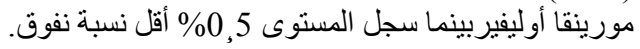

